\title{
Civil Society and Latent Mobilisation Under Authoritarian Neoliberal Governance
}

\author{
Bilge Yabance
}

\begin{abstract}
This chapter reflects on the impact of Turkey's authoritarian neoliberal governance on the transformation of civil society with a particular focus on latent counter-mobilisation. The first section focuses on how Adalet ve Kalkinma Partisi (Justice and Development Party, AKP) has transformed civic space through a selective approach that switches between repression and facilitation. The AKP represses autonomous and dissident organisations and activists through judicial harassment and new regulations while facilitating the growth of a government-oriented civil society sector (GONGOs). The GONGOs fulfil two aims: softening the immediate effects of the state's withdrawal from social provision and generating bottom-up consent for authoritarian neoliberal governance. The second section analyses resistance against the AKP's authoritarian
\end{abstract}

This study has received funding from the European Union's Horizon 2020 research and innovation programme under the Marie Skłodowska-Curie Project 'CRAFT' with Grant agreement ID 795117.

B. Yabanc1 $(\bowtie)$

Ca' Foscari University of Venice, Venice, Italy

e-mail: bilge.yabanci@unive.it

(C) The Author(s) 2022

İ. Borsuk et al. (eds.), Authoritarian Neoliberalism and Resistance in Turkey, https://doi.org/10.1007/978-981-16-4213-5_10 
neoliberalism by focusing on the case of a unique social movement, Müslüman Sol hareket (Muslim Left movement), which fuses class politics with Islamic social justice. Based on insights from original fieldwork and interviews with activists conducted in 2018-2019 in Turkey, the discussion demonstrates that the syncretic amalgamation of socialism with Islamic justice has emerged at the unexpected intersections of ideologies and everyday experiences and challenges simultaneously the AKP's neoliberal exploitation, instrumentalisation and politicisation of religion, and authoritarian governance.

Keywords Authoritarian neoliberalism - Resistance · Civil society · GONGOs · Muslim Left movement

\section{Civil Society and Latent Mobilisation Under Authoritarian Neoliberal Governance}

This chapter reflects on the impact of authoritarian neoliberal governance on the transformation of civil society with a particular focus on latent counter-mobilisation. I aim to capture the complex transformation of civil society under the rule of Adalet ve Kalkrnma Partisi (Justice and Development Party, AKP) (2002-present). The chapter first explores the emergence and the role of new pro-government civil society under the parallel pressures of neoliberalisation and autocratisation. Then, based on interviews with activists conducted in 2018-2019, the second part analyses the syncretic resistance movement by the Müslüman Sol (Muslim Left) against authoritarian neoliberalism. The movement has arisen at the unexpected intersections of socialism and Islam seeking to build solidarity and trust across Turkey's enduring political cleavages (left/right and religious/secular) based on everyday experiences. This unique social movement fuses class politics with Islamic social justice and challenges simultaneously the AKP's neoliberal exploitation, instrumentalisation and politicisation of religion, and authoritarian governance. Moreover, being non-traditionally organised through horizontal networks, the movement remains independent from both political authorities and international donors, decreasing the risk of 'NGO-isation'.

The chapter demonstrates that discretionary oppression and cooptation attempts of civil society under the AKP rule have created pockets 
of resistance within civil society. As the AKP seeks ways of consolidating its authoritarian politics through civil society, the very means of resistance in and through civil society are also fundamentally reconfigured. Resistance becomes more grassroots-anchored and creates opportunities to articulate grievances through alternative frames and new channels of mobilisation.

\section{High Hopes, Shattered Dreams: A Short Story of the Neoliberalisation of Civil Society}

After the role that grassroots mobilisations played in the democratic transitions in Central and Eastern Europe (Merkel, 2004; Toepler \& Salamon, 2003) and Latin America (Feinberg et al., 2006), civil society has become associated with individual and group freedoms and democratic demands (Rosenblum \& Post, 2002). In the 1990s and 2000s, the rise of associational activity was a welcome sign of democratisation (e.g. Fisher, 1998). The European Union, the World Bank, and the United Nations invested in large-scale civil society promotion programmes in this period. Nevertheless, international donors followed 'one size fits all' recipes and pushed for the maximum professionalisation or what is termed as the 'NGO-isation' of civil society in the developing and middle-income countries. More professionalisation in the NGO sector was perceived as a sign of cultivated pro-democracy citizenry that could counter abusive and incapable state power (Alvarez, 2009).

The highly professionalised NGO sector has turned out to be more accountable to donors due to financial dependence than to the societies that they were supposed to serve, and hence devoid of grassroots connections (Chandler, 2006). For Kamat (2004) and Petras and Veltmeyer (2005), the professionalisation of civil society has also fashioned depoliticised and privatised social work. In line with this neoliberal logic, civil society has increasingly been mobilised for delivering services that states could not or would no longer provide. NGOs that have come to dominate civil society in several developing and democratic transition contexts have fulfilled duties as service providers in poverty alleviation, but local-level improvements have actually maintained 'the existing power structures [and inequalities] intact' (Petras \& Veltmeyer, 2005, p. 20). Project management and bureaucracy have come to dominate civil society and divert resources and attention away from mobilisation for social change towards institutional survival and maintenance at the expense of mobilization' (Choudry \& Kapoor, 2013, p. 5). As service providers, 
NGO-ised civil society has become less rights-oriented and increasingly marketized and/or neutralized with regards to political critique and contestation' (Jessen, 2017). Roy (2011, p. 43) rightly argues that NGOs' 'real contribution is that they defuse political anger and dole out as aid or benevolence what people ought to have by right'.

More interestingly, authoritarian rulers have quickly learned to appropriate the neoliberal and depoliticised civil society model for their own resilience (Froissart, 2014; Giersdorf \& Croissant, 2011). Authoritarian regimes allow and even encourage associational life to flourish through promoting civil society organisations, provided that they act within the limits set by the political authorities (Alagappa, 2004). Knowing that an anti-systemic approach would mean institutional death, the majority voluntarily accepts co-optation and work within the limitations imposed by the authoritarian incumbents (Lewis, 2013; Rivetti, 2017; Wischermann, 2011; Ziegler, 2010). It would not be wrong to claim that authoritarian regimes have repoliticised civil society through creating government-oriented civil society organisations (GONGOs) (Hasmath et al., 2016). GONGOs have some autonomy in terms of membership and activities but remain dependent on authoritarian governments for funding and claims-making (Yabanc1, 2016). In a clientelist relationship, a civil society dominated by GONGOs channels grievances into acceptable forms of complaint (Balzer, 2003) and, therefore, promotes 'acceptable' forms of claims-making that do not threaten the regime and autocratic incumbents (Cheskin \& March, 2015; Choudry \& Kapoor, 2013, pp. 5-6; Teets, 2013). GONGOs also provide a democratic disguise that authoritarian regimes desperately need as a façade of democratisation to attract international aid and acclaim (Hawkins \& Hansen, 2007; Ziegler, 2010).

Moreover, authoritarian regimes often resort to civil society as trusted partners by utilising them in service provision where they want to cut state spending (Spires, 2011). GONGOs provide a safety valve by absorbing some of the cuts in state spending, hence making the reduced role of the neoliberal state acceptable for societies. For instance, Islamic associations in the Middle East have been providing charitable service to the poor for decades (Clarke, 2006; Liverani, 2008; Zubaida, 1992). In China, GONGOs have been used to carry out experimental social policies and served as a potential 'lightning rod' by shielding the party from popular reactions (Hasmath et al., 2016). Yaworsky's (2005, pp. 406-407) study 
on Mexican civil society during the absolute rule of the Partido Revolucionario Institucional also shows how civil society has been employed to provide basic welfare to rural populations while extracting 'political quiescence' and 'implementing the government program of trade liberalization'.

To sum up, the neoliberal restructuring of the state has coincided with high hopes related to the democratising power of civil society and has led to partial substitution of the state with civil society as service providers. This has led to increasing depoliticisation and NGO-isation as civil society became detached from the grassroots in many countries. Authoritarian regimes have appropriated this depoliticised civil society model and repoliticised it through co-optation and GONGOs as ideological carriers and service providers for their own resilience.

\section{Authoritarian Neoliberalism and the Transformation of Civil Society in Turkey}

In Turkey, civil society has always been circumscribed by the state because of its decentralising and mobilising potential (Toprak, 1995). Following the 1980 coup, the military junta abolished all civic organisations and imposed severe restrictions on the freedoms of assembly and association. The early years of the AKP and the short-lived EU integration prospect were a brief interruption in the statist approach to civil society in which civil society's expansion was facilitated through a number of reforms (Diez et al., 2005; Yabanc1, 2019a).

After the 2013 Gezi protests, as the authoritarian tendencies intensified, the AKP has adopted a two-fold strategy towards civil society. On the one hand, it has selectively repressed the civic space by targeting critical voices and contentious mobilisation. Turkey's civil society currently faces impediments in establishing new organisations or offices and accessing foreign funding, and suffers from pre-emptive detention, restrictions on the freedom of association as well as more subtle forms of political repression such as compulsory notification for new members (CIVICUS, 2018). Following the 2016 coup attempt, this repression became more evident when 1412 associations and 139 foundations were closed under the state of emergency measures without due court proceedings. In December 2020, the government passed a new law titled 'Preventing Financing of Proliferation of Weapons of Mass Destruction'. While the law allegedly tackles terrorism, in practice it opens up the way for curbing legal activities 
of civil society organisations. The draft law foresees annual inspections, high fines for fundraising that is deemed 'unlawful', and the suspension of the entire board of an organisation if a criminal investigation is underway concerning a member of the board. Given that civil society and activists often face terrorism charges in the aftermath of the 2016 coup attempt, the draft law clearly aims to paralyse autonomous civil society organisations and even replace their leadership in line with the repoliticisation of civil society for authoritarian resilience.

Meanwhile, civil society organisations with ideological and organic links to the AKP have been actively promoted (Yabanc1, 2019a). GONGOs have allowed the AKP to appropriate civil society for the sake of the parallel processes of neoliberalisation and autocratisation. First, the state's withdrawal from social welfare provision has reached a peak during the AKP years (Tansel, 2018). While remaining loyal to the neoliberal model, realised through increased precarisation of labour and privatisation of social services, the AKP has evaded alienating the urban and rural poor. GONGOs have become key partners towards this end by filling the gap in the provision of essential services as service deliverers in key sectors, such as education and social assistance (Eder, 2010).

GONGOs carry out projects tailored for targeted social groups, particularly for youth and women, such as jobs and skills training on popular and contemporary subjects, the provision of aid, counselling and dormitories, and opportunities for entrepreneurship linked to access to microcredits. Packaged as 'voluntarism' and 'charity' embedded in the Turkish culture, several organisations also provide cash and in-kind benefits to the poor and other disadvantaged groups, such as refugees (Yabanc1, 2019b). Government-oriented civil society has also become a key sector that also offers jobs, income, social mobility, and even housing to their volunteers and members. As a result, a self-reproducing system of clientelism within civil society has become a major factor for the appeal of GONGOs in Turkey (Yabanc1, 2016, 2019b). In this state-civil society relationship, civil society has become the state's trusted partner that shares the burden of welfare provision, reflecting the major neoliberal conviction that the state should not be responsible for the provision of essential social aid and 'poverty can be eradicated through private entrepreneurship and work' (Eder, 2010, p. 179).

To pool resources for their activities, the AKP has encouraged private donations to GONGOs and Islamic brotherhoods. The practice of private 
contributions is presented as the legacy of the Ottoman charity tradition. Towards this end, the government has eased the bureaucratic processes for donations through the decisions by the Council of Ministers that grant these organisations public benefit status. Additionally, concerning key social groups such as the urban poor, women, and youth, the government has promoted specific associations and foundations to open branches across Turkey through subsidies in the form of providing premises and funding projects through ministerial or municipal budgets (Yabanc1, 2019a).

Second, thanks to these subsidies and bureaucratic facilitation, GONGOs have established grassroots links with different social and electoral groups. Through these links, they do not only actively work for electoral gains but also seek to garner support for policies and extinguish societal reactions against controversial policies and authoritarian practices in urban and rural areas alike (Yabanc1, 2019a). They skillfully utilise the classical repertoire of social movements such as protests, press statements, and public awareness campaigns to legitimise the AKP's controversial legal amendments and disseminate a nationalist-conservative and militarist worldview among their members and followers. One case in point is the 2017 legislative change giving religious authorities (muftis) the right to perform civil marriages. While feminist women's organisations objected to the proposal mainly because of its potential to force women into unwanted or early marriages, women's organisations with organic ties to the AKP formed a counter-bloc to defend the proposal as 'being in line with the widely-accepted local traditions' (Sol Gazete, 2017). More recently, government-oriented women's organisations whitewashed the AKP's proposal that foresaw the suspension of prison sentences for the sexual abuse of the underage under the condition of marriage. Although not directly defending the government proposal due to the widespread public backlash, even from the conservative segments of society, they have tried to distract public attention by arguing that the government does not try to support underage marriages or pardon sexual abuse but rather seeks to prevent the break up of family unions when consensual marriages involve an underage woman (KADEM, 2020). Cheskin and March (2015) coined the term 'consentful contention' to describe contention presented in ways acceptable or at least not irritating from the autocrats' perspective. Government-oriented women's organisations engage in such consentful contention. Meanwhile, they seek to ease the 
public reaction by offering a justificatory coating and gradually prepare the public for legal changes on controversial issues.

Similarly, government-oriented youth organisations disseminate a nationalist-conservative worldview among youngsters by using the mobilisation repertoire of social movements. To fulfil their aspiration of creating the future generation of AKP supporters, they seek to cultivate national pride and pro-government sentiments among the youth and hence 'mould youngsters' self-perceptions, identities, political attitudes, and loyalties' (Yabanc1, 2019b, p. 28). To this end, they have benefited from the privatisation of education and the vacuum left in the supply of education-related services like dormitories, extracurricular courses, and scholarships after the crackdown on the Gülen community (Kandiyoti \& Emanet, 2017; Yabanc1, 2019b). These organisations attract youth from primary school age to early career professionals through private schools, scholarships, summer camps, dorms, and extracurricular training activities. When they engage in these activities and socialise within the circles of government-oriented youth organisations, youngsters become exposed to nationalist-conservative indoctrination, a revisionist reading of history that celebrates irredentist and imperialist ideas in line with the AKP's neo-Ottomanist project and its reflections on youth policy (Chapter 7 in this volume; Gençkal-Eroler, 2019; Tokdogan, 2018; Yabanc1, 2019b). Becoming a part of the inner circle of a nepotistic and politicised public jobs market is also an appealing factor among youngsters who join these organisations where they reach networking and job opportunities (Yabanc1, 2019b).

To summarize, as Eder argues by "enabling “certain" NGOs ... the state also appears to extend its political power' $(2010, \mathrm{p}$. 181). In complementing the neoliberal state, GONGOs have facilitated authoritarian governmentality in line with the AKP's political project of cultivating pious and nationalist citizenry and imposing an alternative cultural hegemony. Authoritarian neoliberalism has engendered patron-client relations within civil society and pushed civil society to develop vertical ties with governments. 


\section{A Bridge Over the Enduring Cleavages: Fusion of Class Politics with Islamic Social Justice}

The authoritarian neoliberal model has created its counterforce within civil society. Having no meaningful access to monopolised political institutions, civil society has become a dynamic ground to organise oppositional mobilisation from the bottom-up in Turkey. One of the novel actors of this ground is the Muslim Left movement.

The entanglement of Islam and socialism has a long history with roots developed autonomously from each other including the Third-Worldist movement and the ideologically distinct revolutions in Russia and Iran (Cesur, 2017; Paracha, 2013; Saffari, 2017; Tripp, 2006). Within the Turkish context, Islam is historically considered the antithesis of socialism. This situation can be explained by Cold War politics aimed to constrain the appeal of leftist ideologies within the Western bloc. Additionally, in Turkey, state secularism has sought to create 'state Islam' limiting the influence of the anti-statist and anti-nationalist nature of political Islam. As a result, the two major ideological currents of the twentieth centuryIslamism and socialism-remained separate, if not hostile to each other, during the 1960s and 1970s in Turkey.

Some exceptions existed but failed to amplify their voices. Within some factionary leftist circles, prominent activists/intellectuals (e.g. Mihri Belli and Hikmet Kivilcimli), also influenced by Third-Worldism, argued that socialists and communists in Turkey had been alienated from the masses (for a review of this argument, see Karpat, 2004). While the discussion among some leftist groups revolved around the possibility of a unique 'Turkish socialism', some figures within Islamist intellectual circles (e.g. Nurettin Topçu) started to embrace ideas akin to social justice and anticapitalism (Guida, 2013; Taskin, 2007). The Iranian Revolution and the 1980 coup in Turkey contributed to the appreciation of socialism among some Islamist circles (Elhan, 2015). ${ }^{\mathrm{l}}$ However, the efforts to bridge Islam and socialism remained at the fringes of the leftist and Islamist mobilisation and were staunchly denounced by the mainstream ideologies of both camps.

During the AKP era, more concrete attempts have been taken to bridge what remained at the fringes of leftist and Islamist circles. Intellectual efforts and an activist repertoire towards the making of a Muslim Left movement intensified in the aftermath of the 2010 constitutional referendum. According to Hasan, ${ }^{2}$ the failure of the Has Party as a synthesis of 
Table 10.1 Active Platforms, Networks, Associations, and Trade Unions that emerged from the synthesis of socialism and Islam(ism)

\begin{tabular}{|c|c|c|}
\hline Name & Since & Areas of Activity \\
\hline $\begin{array}{l}\text { Emek ve Adalet Platformu } \\
\text { (EAP)/Labour and Justice Platform }\end{array}$ & 2011 & $\begin{array}{l}\text { The platform organises public lectures } \\
\text { and solidarity events with workers. } \\
\text { Zeki Kilıçarslan and Mehmet } \\
\text { Bekarogglu are highly revered among } \\
\text { the activists }\end{array}$ \\
\hline $\begin{array}{l}\text { Anti-Kapitalist } \\
\text { Mïsliumanlar/Anti-Capitalist Muslims }\end{array}$ & 2013 & $\begin{array}{l}\text { Platform organised around İhsan } \\
\text { Eliaçı }\end{array}$ \\
\hline $\begin{array}{l}\text { Toplumsal Dayanışma, Kültür } \\
\text { Eğitim ve Sosyal Araştırmalar } \\
\text { Derneği (TOKAD)/Social Solidarity, } \\
\text { Culture and Social Research } \\
\text { Association }\end{array}$ & 2007 & $\begin{array}{l}\text { Trade union based in Tokat with an } \\
\text { Istanbul office }\end{array}$ \\
\hline $\begin{array}{l}\text { Hak ve Adalet Platformu/Rights and } \\
\text { Justice Platform }\end{array}$ & 2016 & $\begin{array}{l}\text { The platform organises public lectures } \\
\text { and press statements. It has been } \\
\text { particularly active in voicing the rights } \\
\text { violations targeting the people sacked } \\
\text { or persecuted after the } 2016 \text { coup } \\
\text { attempt }\end{array}$ \\
\hline Hak İnisiyatifi & 2017 & $\begin{array}{l}\text { An Ankara-based association } \\
\text { established after the removal of the } \\
\text { top echelons of Mazlum-Der by a } \\
\text { pro-AKP clique }\end{array}$ \\
\hline $\begin{array}{l}\text { Tarlabaşı Dayanışma/Tarlabaşı } \\
\text { Solidarity }\end{array}$ & 2013 & $\begin{array}{l}\text { Refugee support network, based in } \\
\text { the working-class district Tarlabaş1 in } \\
\text { Istanbul. Their activities focus on } \\
\text { African migrants in İstanbul }\end{array}$ \\
\hline İstanbul Dïşünce Evi & 2013 & $\begin{array}{l}\text { Officially organised as an association, } \\
\text { the network organises public lectures } \\
\text { and discussions }\end{array}$ \\
\hline Özgür Eğitim-Sen & 2011 & $\begin{array}{l}\text { Trade union based in Ankara for } \\
\text { workers in the education sector }\end{array}$ \\
\hline $\begin{array}{l}\text { Isscinin Kendi Partisi } \\
\text { (İKEP)/Workers' Own Party }\end{array}$ & 2019 & A recently founded political party \\
\hline
\end{tabular}

the left and Islamist ideologies and the co-optation of its leadership by the AKP have motivated a group of intellectuals and a young generation of activists from an Islamist or religious background to search for 'an alternative way' outside party politics (August 2018, İstanbul). As a result of these efforts, several informal networks and organisations have emerged. Table 10.1 provides a list of the most active platforms, networks, associa- 
tions, and trade unions that emerged from the synthesis of socialism and Islam(ism).

These Muslim Left groups fit into the classical definition of social movement organisations due to their horizontal structures and mobilisation repertoires. They are strictly opposed to being defined as civil society organisations due to the term's connotations with professionalised NGOs in Turkey. During my fieldwork, I realised that activists often avoid ideological labels. Foremost, they reject the label of Islamist. During our formal or informal interviews, activists often mocked selfdefined Islamists. Some activists also reject the label of 'Muslim Left'. In the words of Yasin, 'we have never used Muslim Left or leftist Islam to define ourselves. These artificial labels are attributed to us from the outside. We just demand local and collectivist social justice' (June 2019, Ankara).

There is also no broad-based agreement among these groups about the future of the movement. The diverse organisational structures reveal this lack of a common vision for the future. Groups range from loose networks of like-minded people to associations, trade unions, and even a political party in the making. Bekir mentioned that 'our movement is driven by comradeship, individual creativity, initiatives, contemplation and links based on trust' (August 2018, İstanbul). Similarly, Cafer told me that 'their platform is an idea'. In his own words:

I do not agree with the labelling as a civil society organisation. Civil society organisations can only be instruments. An idea and its societal resonance are more meaningful. An idea can be copied and reproduced in more than one place at any time. An idea does not rely on a name, physical location or a banner. By its nature, it is stronger than a civil society organisation. (February 2019, İstanbul)

This conviction that the Muslim Left movement should stay as an idea is not shared by all activists. Hasan defined their group 'as a platform in search of novel politics' and a political party in the making.

Despite these differences in their vision for the future, the same reasons brought people together. Foremost, everyone identified with the Muslim Left movement was disappointed with both the leftist and Islamist ideology and sought alternative solutions to what they deem to be salient problems. The EAP's principal declaration is a good exemplar: 
[The Platform] aims to contribute to the struggle for justice against discrimination and tyranny. The exploitation of labour by the capital is a form of tyranny. ... We offer an intellectual and action-oriented platform for people working towards the same goal but were disconnected from each other in the past. This way, we aim to inject new energy into politics and build a common action ground for all who fight against the enslavement of humans. We pursue a discourse and politics for radical societal justice without taking refuge in a single political ideology and falling into the trap of elitism. One of our main action areas is to demolish the otherisation between Islamists and socialists. The possibility of generating a common discourse and action platform for religious and secular social justice is not only meaningful for our country but also for the search for rights and justice by the downtrodden worldwide. (EAP, 2019)

Activists coming from an Islamist or religious background are also motivated to contest the AKP's claim over the Islamist heritage in Turkey. Their objection to the AKP is two-fold. First, they criticise the neoliberalisation of the economy and social life. Namely, during the AKP rule, Islam has been used to justify precarity created by privatisation, the commodification of labour, and the financialisation of the economy. The neoliberalisation of the economy has created and, to date, sustained party clientelism. While the AKP resorts to selective delivery of services and perks to certain segments of society, arguments with religious connotations (e.g. fate, ordeal by God) are used to justify poverty (Cosar \& Yegenoglu, 2009; Isik, 2012). Besides, a new conservative middle class has thrived financially thanks to clientelism and patronage. This enriched Islamist bourgeoise is assertive of its partisan affiliation in everyday life through displays of neoliberal consumption culture injected with a religious taste, such as clothing, home decoration, emphasis on 'no alcohol', luxurious holidays abroad in Muslim territories, or gender-segregated resort hotels (Öncü \& Balkan, 2016). Muslim Left activists denounce this multilayered neoliberalisation of society which is epitomised by, on the one hand, increased income inequality and on the other, increased poverty justified through Islamic arguments and the posh lifestyle of co-opted Islamist bourgeois. According to Erol, the AKP 'has spread a morality that is contrary to Islamic morality' (June 2019, İstanbul).

Second, Muslim Leftist activists also oppose the AKP for its antidemocratic politics. Engin mentioned his personal motivation for joining the platform that is also shared by several other activists: 
When I initially chose political Islam, my motivation was to help to establish 'a better world'. Then, I became convinced that this ideal cannot be realised through traditional venues and the rhetoric of Islamists. I started voicing my conviction within our circles that we need to get in touch with the leftist and oppositional circles with whom we share the humanist values and the view that this system should be transformed. My conviction was entrenched as the AKP has become more empowered politically, Islamists started to prefer personal gains over ideals. (June 2018, İstanbul)

Their participation in the 2013 Gezi protests made these groups visible to many other oppositional groups. Following 2013, the Muslim Left movement has adopted a unique action repertoire and taken a respected place among the oppositional civil society. The rest of the chapter turns to analyse how the Muslim Left movement communicates its ideas through frames and mobilises its base.

\section{Framing of the Movement's Goals}

Social movements 'frame' grievances to amplify the feelings and demands of certain groups. In doing so, they resort to symbols, cultural references, emotions, fears, and anxieties as well as historical narratives. Frames 'underscore and embellish the seriousness and injustice of a social condition or redefine as unjust and immoral what was previously seen as unfortunate but perhaps tolerable' (Snow \& Benford, 1992, p. 137). Tarrow (2012, p. 156) states that 'out of a cultural reservoir of possible symbols, movement entrepreneurs choose those they hope will mediate among the cultural understandings of the groups they wish to appeal to, their own beliefs and aspirations, and their situations of struggle to create solidarity and animate collective action'. The uniqueness of the frames used by Turkey's Muslim Left movement derives from an amalgamation of class politics focused on labour rights and Islamic principles of equality and justice.

Accordingly, labour rights, equality for subaltern groups, and social justice are inalienable and constitute the core of the Islamic doctrine. In this sense, they conjecture a counter-hegemonic argument against neoliberalism. Interpreting Islam from justice, freedom, and equality perspectives, they argue that Islamic teachings are socialist in core and 
there is a class orientation within Islam that calls for the radical restructuring of the capitalist and neoliberal hegemony. Some figures of the movement defend this position with references to Quran to 'prove' that Islam embraces or even precedes socialism (Eliaçı, 2007). My interviews with activists from different groups revealed that the Muslim Left movement considers that socialism is realised best when articulated through Islam and also an Islamic society should be reinterpreted as a form of socialist brotherhood. This approach to Islam has also challenged the mainstream theological interpretation of haram ('forbidden' acts) by redefining haram as forced labour, modern slavery, and the lust for unjust accumulation of wealth ( hakszz kazanç).

The Muslim Left movement refuses to be identified with a single ideology. As the most obvious example, IKEP promotes the motto 'neither the left nor the right of the bosses' and claims to be 'the workers' own party'. This denial of the left-right dichotomy constitutes the Muslim Left antithesis of the AKP-championed fusion of neoliberalism, Islamic lifestyle, crony capitalism, and popular culture. ${ }^{3}$ One of the major focus areas where the movement frames its goals is occupational hazards due to employment conditions. When the disastrous 2014 Soma mine accident killed 301 miners, government officials, including Erdoğan, claimed that such accidents are in the nature (fitrat) of jobs in the mining sector, choosing evidently Islamic wording. Muslim Left activists object to this fatalism justified through religious framing. They claim that deadly labour accidents are the result of political decisions, not fate. Accordingly, the current system maximises the employers' earnings at the expense of workers. In this sense, this movement also criticises mainstream trade unions for being a part of the neoliberal disciplining of organised labour and clientelist networks. In the words of Feyyaz, trade unions seek 'to secure their place in the bureaucracy and share some benefits distributed by the government' instead of fighting for labour rights (May 2019, e-mail).

The Muslim Left movement has also displayed a pro-Kurdish and pro-immigrant stance connected to its anti-neoliberalism and antiauthoritarianism. As explained by Erol, the AKP electorate behaves cynically as they are sensitive about Palestinians, Uighurs, Rohingyas, and Bosnians, but are 'ignorant towards the torture and discrimination targeting Kurds in Turkey' (June 2019, Ankara). They particularly criticise the utilisation of Syrian refugees in international diplomatic negotiations. Some groups, e.g. Tarlabaşı Dayanışma, focus particularly on more discriminated and ignored immigrants from African and non-Muslim 
backgrounds based on a rights and social justice framework. This is a response to increasing xenophobia in society as well as to the AKP's depiction of Syrian refugees as 'acceptable' immigrants with historical and religious ties due to the Ottoman Empire but total lack of comprehensive policy towards immigrants/refugees from other regions. Those who do not fit in the AKP's historical and religious narrative are discarded and ignored (July 2019, İstanbul).

With its particular framing, the movement appeals to precarious and subaltern groups in Turkey, such as the urban poor, workers, immigrants as well as students, women, and exploited low-middle classes, regardless of their citizenship or ethnic situation.

\section{Contentious Action Repertoire}

The mobilisation repertoire of the Muslim Left Movement reflects the syncretic amalgamation of Islamic modesty and the 'leftist fervour'. Activists argue that strikes, protests, and demonstrations are compatible with Islam and should be a part of their action repertoire. Yet, they diverge within the movement in terms of the forms and aims of street mobilisation. For instance, EAP activists highlight that they intentionally keep the platform's name 'off the stage' and instead prioritise the voices of the oppressed. Unlike a typical social movement organisation, they do not have a logo or slogan. They are sometimes critical of the 'fringe left' for not going beyond reactionary and performative action. In the words of Mithat, an EAP member,

During the Gezi protests, our name was not visible anywhere, although we participated actively. Instead of devoting resources to the redress of abuses and rights violence, some groups seek to caricature or politicise people who were subject to exploitation and violence. This only serves those who would like to recruit new people for their organisation through such public shows. These attitudes are driven by a top-down approach instead of joint mobilisation and learning. Being democratic means prioritising dialogue and solidarity through an organic relationship. We try to be learners, not teachers, and listeners not narrators [of others' stories]. Our difference from several close-knit, fringe leftist movements becomes obvious at this point. (August 2018, İstanbul) 
Other groups like Tarlabaşı Dayanışma, Hak ve Adalet, and İstanbul Düşünce Evi also prioritise off-the-stage contention, charity, and deliberation. On the preference for 'off-the-stage' contention, Metin stated that.

We have organised a charity fair to support laid-off textile workers to help them financially. We have to show solidarity with those workers who are in need. This can only be done through continuous and organised mobilisation, not through one-off sensational reactions. [We hope that] perhaps from this [type of activities] we will catch a clue for a new societal opposition. (February 2018, İstanbul)

The insistence on avoiding public visibility is quite remarkable and contradicts what social movement theory foresees. Social movements galvanise social or political participation by recruiting a broad social base. To do so, they need to invent unique intra-movement cultures, codes, and discourses. Distinct movement symbols and visibility are deemed essential for sustained movement culture and collective identity (Melucci, 1995). The Muslim Left movement in Turkey seems to take a different route by rejecting visibility and the use of distinctive symbols, slogans, and banners. ${ }^{4}$ For the time being, the uniqueness of their 'framing' seems to be the most attractive aspect of the movement for the followers. According to several respondents, this allows them to engage with issues more directly at the grassroots level without being disturbed by the media reaction. On this point, Nihat stated that 'we are aware of the trends that determine media visibility in Turkey. We know which topics will make us heard and which ones ignored, but we do not take our position according to these trends' (June 2018, İstanbul).

Some groups do not always directly confront the government. On some occasions, they even aimed to reach out to the AKP through personal connections, mainly due to their ideological proximity to Islamist groups in the past. For instance, during a local social awareness campaign for homeless people, some activists also contacted the AKP branch in İstanbul to be able to convey their ideas and develop an action-oriented plan from the government (May 2019, İstanbul). Yet, after initial efforts, they gave up as the AKP representatives were inattentive and even hostile to their initiative because an autonomous initiative that would draw attention to homeless people without any accolade for the AKP did not seem a cause worthy of support for the local party branch. 
To date, the movement has sustained two contentious action campaigns that also exemplify their core mobilisational strategy of keeping their name off the stage. The first is pro-labour activism. To denounce the affiliation of Islam with neoliberalism and to renounce violence within Islamist groups that targeted socialist groups in the 1970s, TOKAD, AntiCapitalist Muslims, and the EAP have started to regularly participate in Labour Day demonstrations. The act is also considered a way to denounce the massacre of 1 May 1977 and announce a break with the past.

Solidarity with labour strikes is also a common mobilisation strategy. Emphasising mutual engagement and a willingness to learn directly from the workers, the Muslim Left groups have developed close relationships with striking workers on many occasions. In 2012, the EAP started to organise a 'conscience and justice watch for deceased workers'. Instead of chanting slogans and clashing with the security forces, the EAP issues press statements, organises silent vigils, and offers the stage to the colleagues and families of workers who died on duty as first-hand testimonials of unprotected and informal labour (EAP, 2017). An early example is their pro-labour mobilisation with Casper workers. In 2011, twenty-two workers were laid off after registering with a left-wing trade union, Birleşik Metal-Isss. To show solidarity, their colleagues decided to join the same trade union. However, the media covered neither the strike nor the solidarity act. The resistance only received support from a few leftist groups. The employer used the support of leftist groups in a smear campaign to label workers as 'communists, terrorist and anarchists'. At this point, EAP decided to step in to amplify their voice through solidarity actions and meetings with the sacked workers (EAP, 201la).

More recently, some Muslim Left groups have organised protests and press statements against the privatisation of sugar factories as a form of capitalist exploitation (TOKAD, 2018). The EAP and IKKEP also supported the protest march of Independent Mining Workers' Trade Union (Bağımsız Maden İşçileri Sendikası) from Soma to Ankara in 2020 (Evrensel, 2020). Activists also stated that they have invited workers like subcontracted textile or domestic workers working under precarious conditions to speak of their own experiences at the seminars they organise. Their aim is not to increase the visibility of their organisation and create popularity but to learn from the experiences of precarious labourers and amplify their voices (interviews June-August 2018).

The second example of innovative and highly popular mobilisation is the fast-breaking events called 'fraternity iftars' during Ramadan. The first 
of these fraternity iftars was organised in 2011 by the EAP as a traditional dinner open to everyone. The location was a deliberate choice. Activists chose a busy street in front of five-star hotels at the Taksim Square in İstanbul. The initial aim was to protest expensive dinners organised in hotels as a public show of religiosity by the conservative upper-middle classes that thrived under the AKP as mentioned earlier. The participation in the initial event went beyond what the organisers had expected and attracted widespread media attention (August 2018, e-mail). However, the media claimed only that the event was a reaction to food waste. Activists decided to organise another iftar and issued a press statement to go along with it:

One-third of the population lives below the poverty line. The expensive iftars for a few people cost around one monthly minimum salary. We do not accept that Ramadan has become a social event that reproduces poverty. Ramadan should be about reawakening and asserting the ideal of an egalitarian society. The problem with luxurious iftars is not only waste and ignorance towards worldwide hunger. The issue is about production and equal share; it is also about wasteful consumption. We are not interested in how people spend their money. We are concerned about how they earn this money. Not understanding and appreciating this aspect means only an incomplete acknowledgement of our cause. (EAP, 2011b)

This direct assertion of their purpose was a turning point, attracting an ever-increasing number of people to the fraternity iftars. In the second week, there were around one thousand people from different sociodemographic and ideological backgrounds. In 2012, the EAP took it a step further and introduced specific themes for each week to raise awareness about subcontracted workers, occupational accidents, street waste-pickers, homeless people, refugees and migrants, and women in shelters. They invited participants from these groups to take the stage. Following this decision, the events assumed a new function as a common platform to discuss or hear about the specific problems of certain socioeconomic groups crushed under neoliberal policies. Their aim is, in the words of Orhan, 'to listen to the voiceless and ignored groups without talking in their name. We amplify their voice' (August 2018, İstanbul). As the EAP iftars have become a performance-critical of neoliberalism and de-unionisation, media attention visibly decreased after the first event. Anti-Capitalist Muslims have continued to organise iftars in Taksim until recently (see Chapter 9 in this volume). As the popularity of Eliaçı and 
Anti-Capitalist Muslims have increased, these public events (known as yeryüzü sofralarn) have become more difficult to tolerate for the government. During the 2020 Ramadan, the police arrested its representatives during the gathering (Bianet, 2020). Overall, public iftars have become a symbolic action of the movement and turned a religious practice into a form of performative resistance and social solidarity for discriminated and dissident groups under authoritarian and neoliberal practices.

\section{CONCLUSION}

This chapter has offered an analysis of the transformation of civil society under the parallel pressures of neoliberalism and authoritarianism through the illustrative case of the AKP rule in Turkey. Neoliberalism is not only about the financialisation and privatisation of the economic sector. It has a social and political impact, particularly in the hands of undemocratic regimes (Bruff, 2014). The appropriation of civil society was originally motivated by an objection to excessive state power. However, the idea of promoting civil society for democratisation and good governance has gone awry in several ways. While the civil society sector expanded in many countries thanks to international aid, civil society has become professionalised, hierarchical, and service-oriented in line with neoliberal hegemony. The lack of grassroots links has also created an apolitical civil society in undemocratic contexts. Moreover, authoritarian regimes have quickly learned to appropriate and repoliticise civil society for their own resilience.

Civil society in Turkey during the AKP era has been deeply transformed in line with the authoritarian neoliberal governance. As the state's withdrawal from social services and key sectors has reached a peak during the AKP rule, civil society's role has been redefined through GONGOs as burden-sharing with the state. Moreover, GONGOs also serve the regime's needs of authoritarian legitimation and obtaining consent from key social groups. These organisations benefit from financial, bureaucratic, and political facilitation. In return, they mobilise what they claim to be a traditional cultural practice of voluntarism and charity. They seek to expand the reach of the ideological and partisan appeal of the AKP. Turkey's GONGOs demonstrate that civil society can be useful allies in the autocratisation process 'by expanding and disseminating social control beyond the formal institutional level' (Yabanc1, 2019b, p. 27). Moreover, government-oriented civil society also aides the AKP in sustaining the neoliberal governmentality of key social groups, demonstrating how 
neoliberalism can rally 'local ideologies, moralities and subjectivities' (Yabanc1, 2019b, p. 28).

However, civil society under neoliberal autocratic pressures is not monolithic. Authoritarian neoliberalism has also triggered novel alliances within civil society. Despite not being completely novel as an idea, the Muslim Left has mobilised at an unprecedented level and become popularised as a social movement during the AKP era. The movement is not a homogenous entity but composed of several networks, trade unions, associations, and platforms. Their syncretic stance aiming to offer a common ground for realising justice and equality demonstrates that the resistance to neoliberal authoritarianism is grounded in the intersections of hardships and grievances and the left-right and secular-religious cleavages. They seek to frame various forms of oppression under neoliberal authoritarian hegemony and debate how Islam can answer and address the socio-economic rights of subaltern and minority groups.

Their reinterpretation of Islam from the working class and precarity perspectives challenges the AKP's instrumentalisation of religion for political ends. Moreover, it also slams the narrow typology of Islam as liberal/moderate versus radical as often promoted in 'Western' right-wing neoliberal circles. The Muslim Left movement's ability to draw upon a unique mobilisational repertoire shows that the alliance of Islamism and socialism is not a short-term political tactic but also a genuine attempt to reconcile radical politics linked with people's struggles and Islamic equality and justice. The future potency and limitations of this movement in reaching out to the wider sections of society should be closely watched as precarity and the economic crisis deepen and affect the wider society in Turkey, and as the opposition increasingly turns to civil society and syncretic forms of coalition-making under the pressure of authoritarian neoliberalism.

\section{Notes}

1. It is also reasonable to argued that socialism's universal claims appealed to Islamists who reject nationalism and states as obstacles for the global Muslim community (ümmet/ummah).

2. The actual names of respondents are changed for anonymity. Dates for interviews are given in parentheses at the end of the quotation.

3 . It should be noted that the rejection of the left-right dichotomy is a recurring theme in Islamist politics and correspond to a self-positioning above 
corrupt and competitive politics. It can be found in Milli Görüş as well as the early manifestos of the AKP.

4. It should also be noted that other groups like Anti-Capitalist Muslims are more willing to engage in visible and direct street mobilisation, such as organising protests, distributing leaflets and other performative contentious action, such as funeral prayers for workers who died on duty or people killed during the Gezi protests.

\section{REFERENCES}

Alagappa, M. (2004). Civil society and political change in Asia. Stanford University Press.

Alvarez, S. E. (2009). Beyond NGO-ization? Development, 52(2), 175-184.

Balzer, H. (2003). Managed pluralism. Post-Soviet Affairs, 19(3), 189-227.

Bianet. (2020). Anti-capitalist muslims detained during fast-breaking meal in Taksim released. https://www.bianet.org/english/human-rights/208218anti-capitalist-muslims-detained-during-fast-breaking-meal-in-taksim-released.

Bruff, I. (2014). The Rise of Authoritarian Neoliberalism. Rethinking Marxism, 26(1), 113-129.

Cesur, E. (2017). Muslim Socialists (in Turkish). Eskiyeni.

Chandler, D. (2006). Empire in denial. Pluto.

Cheskin, A., \& March, L. (2015). State-society relations in contemporary Russia. East European Politics, 31(3), 261-273.

Choudry, A., \& Kapoor, D. (2013). NGOization: Complicity. Zed Books Ltd.

CIVICUS. (2018). State of civil society report. https://www.civicus.org/index. $\mathrm{php} /$ state-of-civil-society-report-2018.

Clarke, G. (2006). Faith-based organisations, civil society and international development. Journal of International Development, 18(6), 835-848.

Cosar, S., \& Yegenoglu, M. (2009). The neoliberal restructuring of Turkey's social security system. Monthly Review. http://monthlyreview.org/2009/04/ 01/the-neoliberal-restructuring-of-turkeys-social-security-system/.

Diez, T., Agnantopoulos, A., \& Kaliber, A. (2005). Turkey, Europeanization and civil society. South European Society and Politics, 10(1), 1-15.

EAP. (2011a, June 6). Casper'a sendika girecek, başka yolu yok! https://www. emekveadalet.org/roportajlar/caspera-sendika-girecek-baska-yolu-yok/.

EAP. (2011b, September 6). Lüks Otel Önü Iftarlarna dair. https://www.eme kveadalet.org/sozumuz/luks_otel_onu_iftarlarina_dair/.

EAP. (2017, August 6). 63. Vicdan ve Adalet Nöbeti'nin Ardindan. https:// www.emekveadalet.org/haberyorum/63-vicdan-ve-adalet-nobeti-haberininardindan-olum-cumhuriyeti-olduk/.

EAP. $(2019,2011)$. Illkeler. Emek ve Adalet Platformu. https://www.emekveada let.org/ilkeler/. 
Eder, M. (2010). Retreating state? Political economy of welfare regime change in Turkey. Middle East Law and Governance, 2(2), 152-184.

Elhan, N. (2015). The impact of Iran-inspired Islam in Turkey: The period between 1980 and 2000 [MSc, METU]. https://open.metu.edu.tr/handle/11511/ 25092.

Eliaçık, I. (2007). Yaşayan Kuran [Living Quran]. Istanbul: Insa Publications.

Evrensel. (2020). Ankara'ya yürüyen Somal madencilere engel sürïyor. https:// www.evrensel.net/haber/388384/ankaraya-yuruyen-somali-madencilereengel-suruyor-madenciye-yolu-ac.

Feinberg, R., Waisman, C., \& Zamosc, L. (2006). Civil society and democracy in Latin America. Springer.

Fisher, J. (1998). NGOs and the political development of the Third World. Kumarian Press.

Froissart, C. (2014). The ambiguities between contention and political participation. Journal of Civil Society, 10(3), 219-222.

Gençkal-Eroler, E. (2019). Raising pious generations (in Turkish). Iletisim.

Giersdorf, S., \& Croissant, A. (2011). Civil society and competitive authoritarianism in Malaysia. Journal of Civil Society, 7(1), 1-21.

Guida, M. (2013). Nurettin Topçu: The reinvention of Islamism in Republican Turkey. Alternatives, 12(2), 15-29.

Hasmath, R., Hildebrandt, T., \& Hsu, J. (2016). Conceptualizing governmentorganized non-governmental organizations. Association for Research on Nonprofit Organizations and Voluntary Action Annual Meeting.

Hawkins, K. A., \& Hansen, D. (2007). Dependent civil society: The Círculos Bolivarianos in Venezuela. Latin American Research Review, 41(1), 102-132.

Isik, D. (2012). The specter and reality of corruption in state and civil society. Comparative Studies of South Asia, Africa and the Middle East, 32(1), 57-69.

Jessen, M. H. (2017). Civil society in the shadow of the neoliberal state: On the depoliticization of civil society, 1992-present. In 42nd Annual Meeting of the Social Science History Association, Montreal, Canada.

KADEM. (2020, April 15). Kamuoyunda Erken Evlilik olarak bilinen konuyla ilgili KADEM olarak görüşümüz. https://kadem.org.tr/kamuoyunda-erkenevlilik-olarak-bilinen-konuyla-ilgili-kadem-olarak-gorusumuz/.

Kamat, S. (2004). The privatization of public interest. Review of International Political Economy, 11(1), 155-176.

Kandiyoti, D., \& Emanet, Z. (2017). Education as battleground: The capture of minds in Turkey. Globalizations, 14(6), 869-876.

Karpat, K. (2004). Studies on Turkish politics and society: Selected articles and essays. Brill.

Lewis, D. (2013). Civil society and the authoritarian state. Journal of Civil Society, 9(3), 325-340.

Liverani, A. (2008). Civil society in Algeria. Routledge. 
Melucci, A. (1995). The process of collective identity. In H. Johnston \& B. Klandermans (Eds.), Social movements and culture (pp. 41-63). University of Minnesota Press.

Merkel, W. (2004). Embedded and defective democracies. Democratization, $11(5), 33-58$.

Öncü, A., \& Balkan, E. (2016). Nouveaux Riches of the City of Minarets and skyscrapers. Research and Policy on Turkey, I(1), 29-45.

Paracha, N. F. (2013). Islamic socialism: A history from left to right. https:// www.dawn.com/2013/02/21/islamic-socialism-a-history-from-left-toright/.

Petras, J., \& Veltmeyer, H. (2005). Social movements and state power. Pluto Press.

Rivetti, P. (2017). Political activism in Iran. Democratization, 24(6), 1178-1194.

Rosenblum, N., \& Post, R. (2002). Civil society and government. Princeton University Press.

Roy, A. (2011). Public power in the age of empire. Seven Stories Press.

Saffari, S. (2017). Beyond Shariati: Modernity, cosmopolitanism, and Islam in Iranian political thought. CUP.

Snow, D., \& Benford, R. (1992). Master frames and cycles of protest. In A. Morris \& C. Mueller (Eds.), Frontiers in social movement theory (pp. 133155). Yale University Press.

Sol Gazete. (2017). Kadınlar sizi unutmayacak: Isste müftü nikahr destekçisi STK'lar. https://haber.sol.org.tr/toplum/kadinlar-sizi-unutmayacak-istemuftu-nikahi-destekcisi-stklar-213799.

Spires, A. J. (2011). Contingent symbiosis and civil society in an authoritarian state. American Journal of Sociology, 117(1), 1-45.

Tansel, C. B. (2018). Authoritarian neoliberalism and democratic backsliding in Turkey. South European Society and Politics, 23(2), 197-217.

Tarrow, S. (2012). Power in movement: Social movements and contentious politics. CUP.

Taskin, Y. (2007). Nationalist-Conservative Intelligentsia (in Turkish). Iletisim.

Teets, J. (2013). Let many civil societies bloom. The China Quarterly, 213, 1938.

Toepler, S., \& Salamon, L. (2003). NGO development in central and Eastern Europe. East European Quarterly, 37(3), 365-378.

TOKAD. (2018). Seker Fabrikalar Halkındrr, Satılamaz! http://www.tokad. org/2018/03/04/seker-fabrikalari-halkindir-satilamaz/.

Tokdogan, N. (2018). New-Ottomanism (in Turkish). Iletisim.

Toprak, B. (1995). Civil society in Turkey. In A. Norton (Ed.), Civil society in the middle east (pp. 87-118). Brill.

Tripp, C. (2006). Islamic socialism. In C. Tripp (Ed.), Islam and the moral economy: The challenge of capitalism (pp. 77-102). CUP. 
Wischermann, J. (2011). Governance and civil society action in Vietnam. Asian Politics \& Policy, 3(3), 383-411.

Yabanc1, B. (2016). Populism as the problem child of democracy: The AKP's enduring appeal and the use of meso-level actors. Southeast European and Black Sea Studies, 16(4), 591-617.

Yabanc1, B. (2019a). Turkey's tamed civil society: Containment and appropriation under a competitive authoritarian regime. Journal of Civil Society, 15(4), 285306.

Yabanc1, B. (2019b). Work for the nation, obey the state, praise the Ummah: Turkey's government-oriented youth organizations in cultivating a new nation. Ethnopolitics, 20(4), 467-99. Retrieved August 08, 2021, from https://doi.org/10.1080/17449057.2019.1676536.

Yaworsky, W. R. (2005). At the whim of the state: Neoliberalism and nongovernmental organizations in Guerrero Mexico. Mexican Studies, 21(2), 403-427.

Ziegler, C. E. (2010). Civil society, political stability, and state power in Central Asia: Cooperation and contestation. Democratization, 17(5), 795-825.

Zubaida, S. (1992). Islam, the state and democracy: Contrasting conceptions of society in Egypt. Middle East Report, 179, 2-10.

Open Access This book is licensed under the terms of the Creative Commons Attribution 4.0 International License (http://creativecommons.org/licenses/ by $/ 4.0 /$ ), which permits use, sharing, adaptation, distribution and reproduction in any medium or format, as long as you give appropriate credit to the original author(s) and the source, provide a link to the Creative Commons license and indicate if changes were made.

The images or other third party material in this book are included in the chapter's Creative Commons license, unless indicated otherwise in a credit line to the material. If material is not included in the chapter's Creative Commons license and your intended use is not permitted by statutory regulation or exceeds the permitted use, you will need to obtain permission directly from the copyright holder.

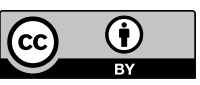

